Instructions for authors, subscriptions and further details:

http://brac.hipatiapress.com

\title{
La Revuelta de Julia Kristeva en la Obra de Louise Bourgeois
}

Alexandra Sans Massó ${ }^{1}$

1) Universidad de Barcelona (España)

Date of publication: February $3^{\text {rd }}, 2016$

Edition period: February 2016 - June 2016

To cite this article: Sans Massó, A. (2015). La Revuelta de Julia Kristeva en la obra de Louise Bourgeois. Barcelona, Research, Art, Creation, 4(1), 65-101. doi: 10.17583/brac.2016.1860

To link this article: http://dx.doi.org/10.17583/brac.2016.1860

\section{PLEASE SCROLL DOWN FOR ARTICLE}

The terms and conditions of use, except where otherwise noted, are related to the Open Journal System and to Creative Commons Attribution License (CCBY). The indication must be expressly stated when necessary. 


\section{Julia Kristeva's Revolt in the Work of Louise Bourgeois}

Alexandra Sans Massó
University of Barcelona (España)

(Received: 31 December 2015; Accepted: 18 January 2016; Published: 3 February 2016)

\section{Abstract}

Julia Kristeva's concept of revolt allows us to consider the work of Louise Bourgeois from different perspectives, encouraging new readings of her artistic production. Revolt, as a remembrance of one's experiences in life through the work of psychoanalysis, the motion of returning to a core theme during more than seven decades of artistic production and the return of the corporeal with its dominance in the sculptural, allows us to get closer to the creative process of one of the most important artists of the 20th and 21 st Centuries.

Keywords: Louise Bourgeois, Julia Kristeva, sculpture, revolt, psychoanalysis, return, corporeal 


\title{
La Revuelta de Julia Kristeva en la Obra de Louise Bourgeois
}

\author{
Alexandra Sans Massó \\ Universidad de Barcelona (España)
}

(Recibido: 31 Diciembre 2015; Aceptado: 18 Enero 2016; Publicado: 3 Febrero 2016)

\section{Resumen}

El concepto de revuelta de Julia Kristeva permite observar la obra de Louise Bourgeois desde diferentes prismas propiciando nuevas lecturas sobre su producción artística. La revuelta, como rememoración de la experiencia vital a través del trabajo del psicoanálisis, el movimiento de retorno a un núcleo temático a lo largo de más de siete décadas de producción artística y la revuelta de lo corpóreo con su preponderancia en lo escultórico, permiten acercarnos al proceso creativo de una de las grandes artistas del siglo XX y XXI.

Palabras clave: Louise Bourgeois, Julia Kristeva, escultura, revuelta, psicoanálisis, retorno, corpóreo 


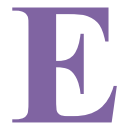

ste artículo propone una lectura de la obra de Louise Bourgeois a través del concepto de "revuelta" de Julia Kristeva ${ }^{1}$. Una vez presentado el concepto de Kristeva, se arguye cómo mediante el psicoanálisis Bourgeois rememora y cuestiona permanentemente su experiencia vital. Se trata de una revuelta interior que practica intensivamente y que permite la reestructuración psíquica, es decir, que aporta concepto y libertad sobre su manera de entender y ser en el mundo, trasladando el aprendizaje a su arte y a la vez, siendo la práctica artística un ámbito de investigación expandido de la práctica psicoanalítica. En segundo lugar esta revuelta en el plano psíquico es correlativa al movimiento de retorno a un núcleo temático que se produce a lo largo de toda su producción artística y que aporta coherencia, consistencia y sobre todo profundidad a su arte. Para terminar, y en un plano más simbólico, es posible entender la obra de Bourgeois como una revuelta hacia lo corpóreo, entendido como la re-presentación ${ }^{2}$ contemporánea del cuerpo, la importancia de lo tangible en su escultura y la fuerte relación que se establece entre el cuerpo de la artista y su cuerpo escultórico.

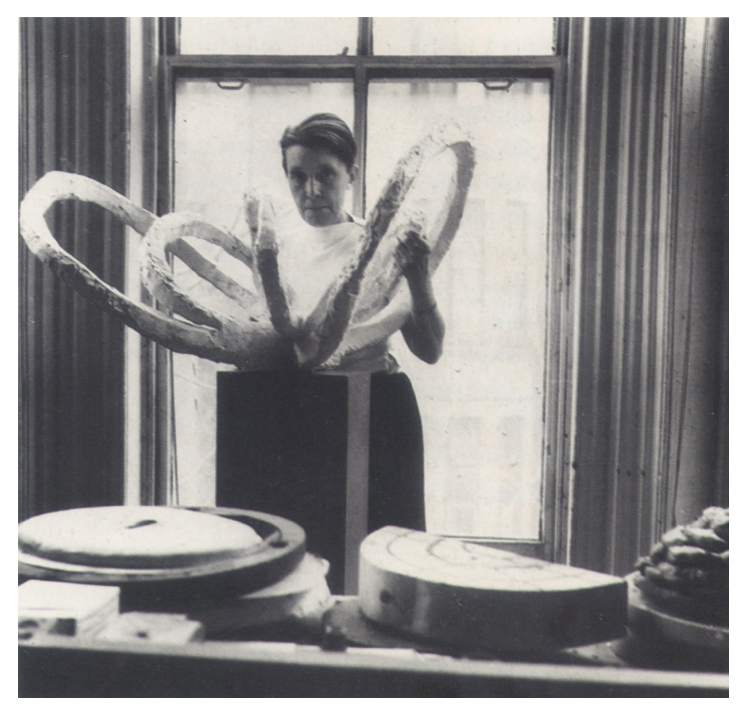

Figura 1. Louise Bourgeois en 1960. (Tàpies et al., 1990, p. 18) 


\section{La Revuelta de Julia Kristeva}

Desde siempre, la poesía ha sabido proclamar la voluntad del libre albedrío, volviendo a la memoria de las palabras para extraer de ella el tiempo sensible. En épocas que oscuramente sentimos en declive o, al menos, en suspenso, el cuestionamiento permanece como el único pensamiento posible. Indicio de una vida simplemente viva. (Kristeva, 2000, p. 9)

Julia Kristeva es una autora reconocida internacionalmente por sus aportaciones en áreas de conocimiento como la semiótica, la filosofía, el feminismo o la narrativa. Su recorrido curricular es apabullante pero aquí sólo se tratará sobre una de sus innumerables aportaciones: el concepto de revuelta expuesto en su libro L'Avenir d'une révolte (1998). Se trata de un texto corto pero su concepción de la revuelta es reveladora y permite establecer diferentes asociaciones con la obra de Bourgeois y su valiosa aportación al pensamiento contemporáneo.

Argumenta Kristeva que durante los dos últimos siglos el antiguo concepto de revuelta -antes cargado de significados y matices- ha quedado reducido a la contestación de normas, valores y poderes establecidos. La revuelta se ha convertido en una especie de mística sinónimo de dignidad. Nos rebelamos contra el estado y contra sus leyes, contra la pobreza y la discriminación. Nos quejamos sobre los impuestos, los precios o las largas colas. Exigimos trabajo para todos y vivienda digna. Queremos educación, sanidad y justicia universal. Nos indignamos como ciudadanos, como trabajadores o como consumidores. Pero en un orden mundial cada vez más globalizado y bajo el poder del capital financiero ¿contra quién nos rebelamos, si los que están no tienen poder o si lo tienen son corruptos? O como dice Kristeva "¿Quién puede rebelarse si el hombre se ve reducido a un conglomerado de órganos, si no es un 'sujeto', sino una 'persona patrimonial', dotada de un patrimonio no sólo financiero sino también genético o fisiológico, que sólo dispone de libertad para zapear y elegir su 'cadena'?” (Kristeva, 2000, p. 14).

[...] no sólo la revuelta política se atasca en los compromisos entre partidos cuyas diferencias son cada vez menos perceptibles, sino que un componente esencial de la cultura europea - una cultura de duda y de crítica- pierde su trascendencia moral y estética. Cuando existe, se la margina y se la acepta a título decorativo, como una coartada tolerada 
por la sociedad del espectáculo; o, simplemente, es engullida por la cultura-entretenimiento [...] (Kristeva, 2000, p. 14)

Kristeva ve con preocupación cómo esta revuelta contemporánea, ante la imposibilidad de vehicular sus demandas a través de los mecanismos políticos y sociales, corre el grave riesgo de transformarse en nihilismo, suspender la interrogación de los propios valores y rechazarlos para dar culto a un nueva estructura de pensamiento que prohíbe la autocrítica y que será tan o más dogmática y opresora que la anterior.

Nunca insistiré lo bastante en el hecho de que el totalitarismo es el resultado de una cierta fijación de la revuelta en lo que constituye precisamente su traición, a saber, la suspensión del retorno retrospectivo, que equivale a una suspensión del pensamiento. Hannah Arendt ha desarrollado brillantemente esta reflexión en su obra Los orígenes del totalitarismo. (Kristeva, 2000, p. 19)

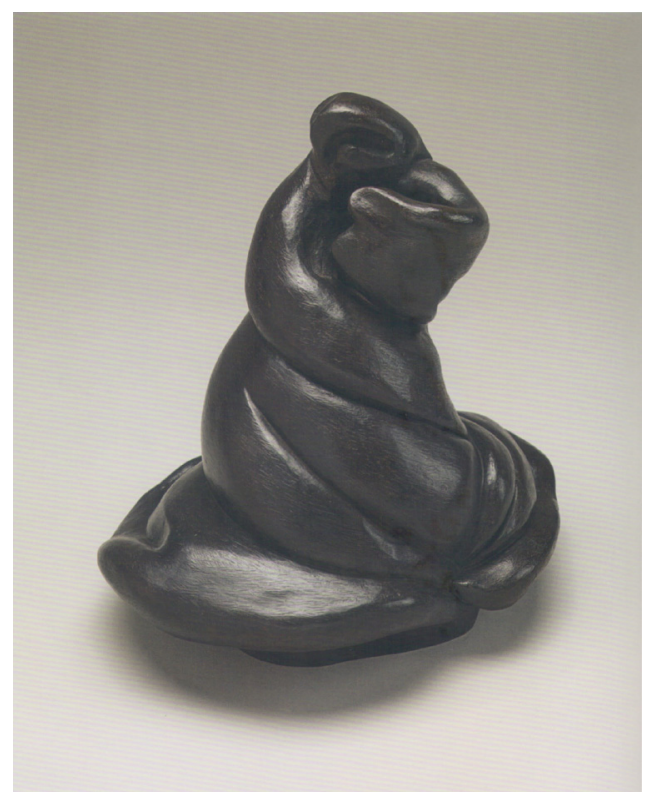

Figura 2. Torsade (1962). Bronce. 20,3 x 20,3 15,2 cm. Foto de Christopher Burke (Larratt-Smith 2012, plate 18) 
La revuelta de Kristeva podría ser sinónimo de "cuestionamiento permanente". Ella quisiera volver a la concepción anterior de revuelta, como una re-vuelta a los orígenes, como un retorno perseverante, un viaje de ida y vuelta que nos permita cuestionarnos sin miedo y cambiar desde quienes somos. Pretende reestablecer el sentido profundo de este término, que en su opinión "caracterizó profundamente a lo más vivo y prometedor de nuestra cultura" (Kristeva, 2000, p. 17). Este concepto está íntimamente relacionado con el "retorno retrospectivo" presente en nuestra cultura desde Sócrates y Platón, y más explícitamente en la teología cristiana en

[...] el redire de San Agustín, fundado en el vínculo retrospectivo con el déja-là del Creador: la posibilidad de cuestionar el propio ser, de buscarse a sí mismo (se quaerere: quaestio mihu factus sum) viene dada por esta aptitud para el 'retorno', que es simultáneamente rememoración, interrogación y pensamiento. (Kristeva, 2000, p. 18)

Por todo lo expresado aquí, se entiende que el concepto de revuelta de Kristeva es una revuelta interior y no exterior, una revuelta de la vida psíquica en todas sus manifestaciones sociales (escritura, pensamiento, arte) y no una en el mundo de la acción. Una concepción de la revuelta que constituye la lógica profunda de la cultura europea, aporta agudeza y cierta libertad, y protege contra dogmatismos y extremismos.

\section{El Psicoanálisis como Revuelta}

En este sentido, el descubrimiento freudiano del inconsciente ha sido el nuevo punto de Arquímedes que ha hecho del psiquismo, que siempre había sido tributario del Otro y de lo otro, el lugar privilegiado donde la vida encuentra su sentido si, y sólo si, es capaz de re-vuelta. Y precisamente sobre este terreno Freud fundó el psicoanálisis como una invitación a la anamnesis, con el fin de llegar a un re-nacimiento, o dicho de otro modo, a una re-estructuración psíquica. (Kristeva, 2000, p. 22)

Kristeva reflexionó y profundizó sobre el concepto de revuelta a través de su larga experiencia práctica y teórica en el psicoanálisis. Para Kristeva, más allá de la anulación del juicio, el analista debe facilitar al analizado la 
donación de sentido durante el proceso de transferencia y contratransferencia (Kristeva, 2000, pp. 30-31). Donar sentido ("por don") equivale al "per-dón" que sucede cuando se reviven experiencias dolorosas para reelaborarlas y poder otorgarles así un nuevo sentido que permita entender los hechos desde otras perspectivas. La finalidad es que el analizado consiga el perdón, perdonar y perdonarse.

Eso significa que en la cultura en re-vuelta se anuncia una verdadera mutación del hombre surgida de la escatología cristiana de la retrospección como vía de la verdad y de la intimidad. Se comprende así que el descubrimiento freudiano no es un rechazo de esta tradición sino su profundización hasta los límites de la unidad consciente, y a partir de ahí solamente la vía freudiana anuncia una posible mutación de nuestra cultura, por cuanto inicia otra relación con el sentido y con el Uno. (Kristeva, 2000, p. 28)

El psicoanálisis sería, pues, una invitación a la rememoración del pasado con el objetivo de renacer simbólicamente, de reestructurar nuestra subjetividad y en algunos casos de regenerarla. Mediante su proceso se podrá dar sentido a la vida y renovar las relaciones y vínculos con los demás, propiciando que aflore la unicidad de cada uno y la propia aceptación.

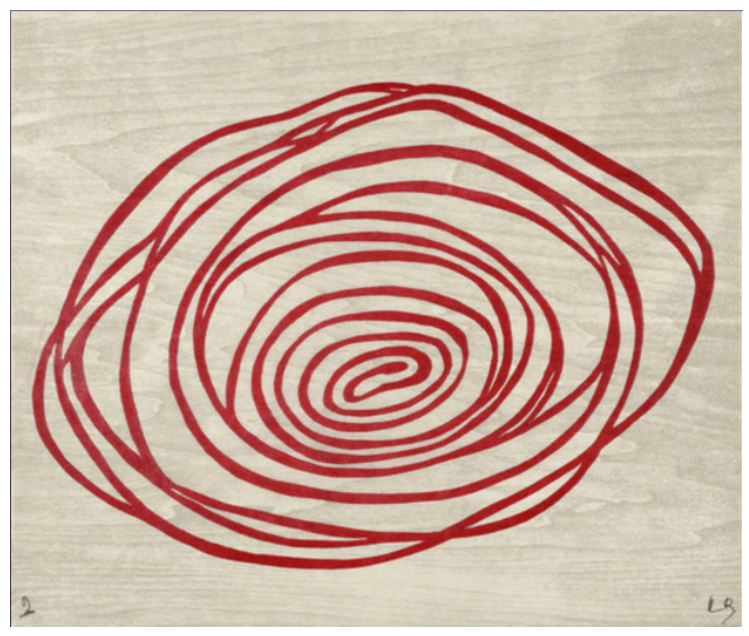

Figura 3. Sin título (serie espirales) (2005). Grabado sobre madera, estampado sobre papel. 35,5 x 42,2 cm. The Easton Foundation. (http://www.moma.org/) 
Digámoslo sin falsa modestia: ninguna otra experiencia moderna, salvo el psicoanálisis, ofrece al hombre una posibilidad de recomenzar su vida. [...] Tal vez esta versión de la libertad sea el regalo más precioso y el de mayor hondura que el psicoanálisis haya hecho a la humanidad. (Julia Kristeva cit. en Paris, 2003, p. 15)

El trabajo del psicoanálisis no consiste propiamente en liberar ni en reprimir, sino en elaborar y reelaborar el aparato psíquico para permitir renovarse con cada prueba interna o externa. (Kristeva, 2000, pp. 4748)

Louise Bourgeois se psicoanalizó durante 30 años y se convirtió en una gran maestra de la re-vuelta psíquica que se expresa en el arte plástico. El psicoanálisis le permitió sobrellevar y reelaborar los acontecimientos más importantes de su vida, pudo conocerse mejor y trabajar para ser más crítica y a la vez, más compasiva consigo misma y su entorno. De acuerdo con Kuspit (2012, p. 18), Bourgeois leyó literatura psicoanalítica e incluso consideró hacer un posgrado de psicología y sociología en la Universidad de Nueva York.

El arte es un privilegio, una bendición, un desahogo [...] Es un privilegio fantástico tener acceso al inconsciente. Tenía que ser digna de ese privilegio, y ejercerlo. También fue un privilegio ser capaz de sublimar. Mucha gente no puede sublimar. No tienen acceso a su inconsciente. Hay algo muy especial en ser capaz de sublimar... y algo muy doloroso al acceder a él. Pero no hay escapatoria... no se puede renunciar al acceso una vez te ha sido concedido, lo quieras o no. (Kuspit, 1988, pp. 67-68)

La rememoración a través de los recuerdos, el acceso al inconsciente y la capacidad de sublimar que desarrolló ampliamente a través del psicoanálisis le permitieron crear estructuras generativas muy fértiles en la creación artística. Bourgeois llevó su investigación psicoanalítica a su arte, dando forma a su psique, a sus pensamientos y a sus emociones, siendo una fuente constante de inspiración. A la vez, el desarrollo de muchos de los conceptos derivados del psicoanálisis en el arte de Bourgeois sirvieron para profundizar la teoría y la práctica psicoanalítica hacia lugares donde no había derivado. Su exploración de la feminidad y de la subjetividad femenina, las relaciones entre madre e hija 
o su representación de la maternidad y los sentimientos asociados a ella, son ejemplos de aportaciones originales al psicoanálisis realizadas por Bourgeois.

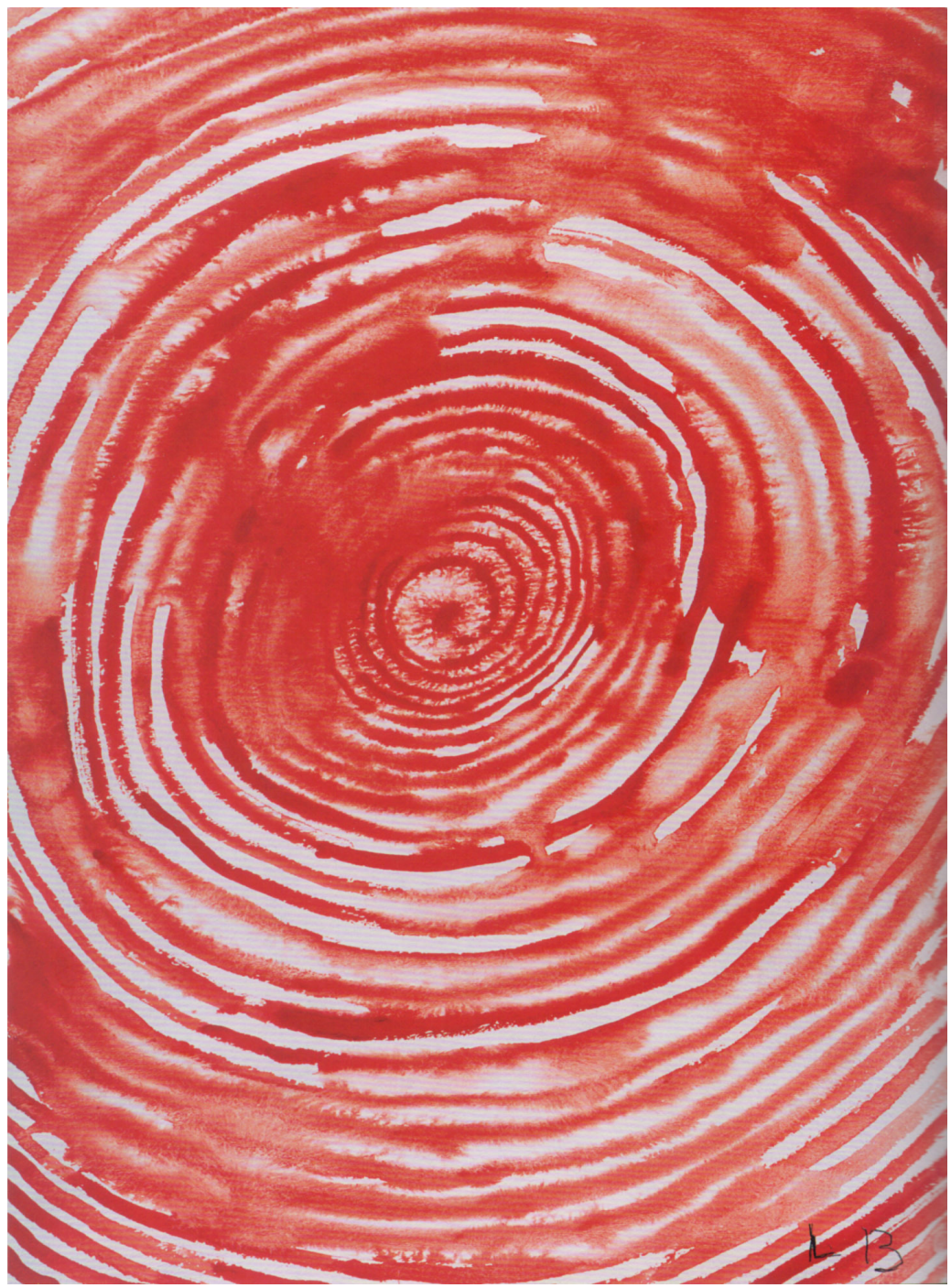

Figura 4. Spiral (2009). Gouache sobre papel. 59,7 x 45,7 cm. Foto de Christopher Burke. (Larratt-Smith 2012, plate 87) 
En 2007 y 2010, Jerry Gorovoy, su fiel ayudante desde 1980, encontró en su casa de Chelsea cajas enteras que contenían notas y escritos de Bourgeois. Los documentos muestran infinidad de asociaciones libres y escritos automáticos que tienen relación con el análisis y con sus conflictos psicológicos. Entre ellos destaca un texto escrito a mano en una hoja suelta que describe la compleja relación de Bourgeois con el psicoanálisis:

El análisis / es un trabajo / es una trampa / es un trabajo / es un privilegio / es un lujo / es un deber / es un deber hacia mí / mis padres / mi esposo / mis hijos / es una vergüenza / es una tarifa /

es una historia de amor / es un rendez-vous / es un juego de gato y ratón / es un entierro / es una broma / me hace impotente / me convierte en policía / es una pesadilla / es mi interés / es mi campo de estudio / es más de lo que puedo manejar / me enfurece / es un hastío / es una molestia / es una lata. (c. 1958 en Larratt-Smith, 2012, p. 6)

Philip Larrat-Smith, editor de los dos volúmenes publicados para la exposición "The Return of The Repressed" (2012), fue contratado en 2003 como archivista del Louise Bourgeois Studio y trabajó intensamente sobre sus escritos hasta la finalización de la mencionada exposición. Para LarratSmith los escritos psicoanalíticos han incrementado nuestra comprensión del trabajo y de la vida de Bourgeois, mostrando "las interconexiones entre su psicoanálisis, sus lecturas especializadas sobre el psicoanálisis, su excéntrica producción artística, su relación con los materiales y su inventiva formal." (Larratt-Smith et al., 2012, p. 14).

$\mathrm{O}$ en palabras de Mignon Nixon:

La revelación de los escritos psicoanalíticos de Bourgeois -un compendio de sueños, síntomas, recuerdos, fantasías, angustias, deseos, y quejas, intercalados con dibujos, anotaciones sobre sus lecturas, reflexiones post-sesión y ocasionales hallazgos de sabiduría analíticason un descubrimiento tan significativo para la historia del psicoanálisis como para la historia del arte. (Nixon, 2012, p. 85)

Una de las ideas más conocidas de Bourgeois, "Art is a Guaranty of Sanity" [El arte es garantía de cordura], transmite la importancia de la práctica artística para abordar temas demasiado dolorosos o complejos para hacerlo de manera consciente. Es decir, el ejercicio artístico propicia espacio y tiempo 
a la psique para que el inconsciente los reelabore y la persona pueda crear nuevas estructuras de pensamiento que permitan entender y representar las inquietudes desde otros puntos de vista, aceptables para la consciencia. Estas nociones quedan reflejadas en las declaraciones que hizo Bourgeois durante el rodaje del film de Marion Cajori y Amei Wallach ${ }^{3}$.

Las conexiones que hago en mi trabajo son conexiones a las que no puedo hacer frente. Son conexiones realmente inconscientes. El artista tiene el privilegio de estar en contacto con su inconsciente, y eso realmente es un don. Es la definición de cordura. Es la definición de autorrealización. (Bernadac, Bourgeois, \& Obrist, 1998, p. 367)

Para Bourgeois, vida, psicoanálisis y arte fueron de la mano durante medio siglo. En una entrevista con Donald Kuspit la artista afirmaría: "El arte no va sobre el arte. El arte va sobre la vida, y eso lo resume todo". (Bernadac , 1998, p. 166)

Y así es todo el arte de Bourgeois, desde sus inicios, está imbuido de su experiencia vital. Pero no es hasta 1982, con la exposición retrospectiva que le dedica el MoMA, cuando Bourgeois a través de un texto que aparece en la revista Artforum (Bourgeois, 1982) cuenta explícitamente y por primera vez su trauma más conocido. Ilustrado con fotografías y acompañado por un texto mordaz, Bourgeois cuenta la traición de su padre, quién en 1922 contrató a una institutriz para enseñar inglés a sus hijos y se convirtió en su amante, viviendo con la familia durante 10 años. Cuando Bourgeois presenta este trabajo, ya tenía 71 años y gozaba de mucha libertad, tanto personal como económica, hacía 30 años que había empezado el psicoanálisis y llevaba más de 40 años produciendo arte.

Pero más allá de la archiconocida historia que protagoniza artículos y catálogos, hay muchos otros sucesos que tuvieron tanta o más importancia en la vida de Bourgeois y que a menudo no se tienen en tanta consideración. Mignon Nixon, apoyándose en la conceptualización de guerra interior y guerra exterior de Gertrude Stein, subraya la influencia que las dos guerras mundiales tuvieron sobre la psique de la artista (Daniel et al., 2007). Bourgeois vivió la Primera Guerra Mundial durante su infancia. Su padre y su tío se alistaron en el frente. Sólo dos semanas después de estar en el campo de batalla su tío fue abatido. La tía y los primos de Bourgeois, que aún eran niños, fueron a vivir con la familia. Su padre fue herido en 1915 y trasladado a un hospital en $\mathrm{La}$ 
Châtre. Su madre, Josephine Bourgeois, lo visitaría en diferentes momentos, acompañada por Bourgeois cuando aún era pequeña.

Terminada la guerra, en 1921, la madre de Bourgeois contrajo la gripe española. La enfermedad la acompañó hasta su muerte once años más tarde. Durante el último periodo de la enfermedad, Bourgeois interrumpió su educación para cuidarla. En septiembre de 1932 -cuando Bourgeois tenía 21 años- perdió a su madre.

En 1938 Bourgeois emigró a Estados Unidos después de casarse con Robert Goldwater. Los siguientes serían años difíciles. Por un lado Bourgeois se angustió ante la idea de no poder concebir, motivo por el cual el matrimonio decidió adoptar a Michel Olivier en 1939 (Greenberg \& Jordan, 2003, p. 35). El destino quiso que en los dos siguientes años nacieran sus dos hijos biológicos, Jean-Louis Thomas en 1940 y Alain Mathieu Clément en 1941. De manera que en un corto periodo de tiempo Bourgeois tuvo que compaginar su labor artística con el de ama de casa y madre de tres hijos. En segundo lugar, en mayo de 1940 empezó la ocupación nazi de Francia. Nixon explica como Bourgeois y muchos otros artistas franceses exiliados en Nueva York sufrirían sentimientos de melancolía, ansiedad, culpabilidad y pérdida. En junio de 1945, durante el mismo mes en que Bourgeois tuvo su primera exposición individual, coorganizó una exposición de tributo: "Documents France 19401944: Art-Literature-Press of the French Underground". Se trataba de una declaración de solidaridad con la resistencia y con artistas y escritores que se habían quedado en Francia durante la guerra.

Para Nixon el hecho de que Bourgeois continuara trabajando como artista cuando la guerra y los muertos se sucedían en Francia, podría haber sido considerado como un rechazo al duelo (Daniel et al., 2007). Pero en lugar de someterse a la muerte psíquica -reacción que tienen algunos supervivientesla respuesta de Bourgeois fue hacer del arte un trabajo de duelo ampliado, y a su vez hacer que el duelo fuera una manera de estar vivo.

En 1952 muere el padre de Bourgeois. Ese mismo año la artista empezaría las sesiones de psicoanálisis con Henry Lowenfeld, que continuaron intermitentemente y con diferente intensidad hasta 1985, año en que murió el doctor.

Bourgeois, en revuelta constante, rememoraría, reelaboraría y desplegaría estos y otros acontecimientos de su vida a través del psicoanálisis y del arte.

Necesito mis recuerdos. Son mis documentos. Los vigilaré. Son mi 
privacidad y soy intensamente celosa de ellos. [...] Hay que diferenciar entre recuerdos. ¿Va a ellos o están viniendo a usted? Si usted va a ellos, usted está perdiendo el tiempo. La nostalgia no es productiva. Si vienen a ti, son las semillas de la escultura. (1992, cit. en Bernadac et al., 1998, p. 223)

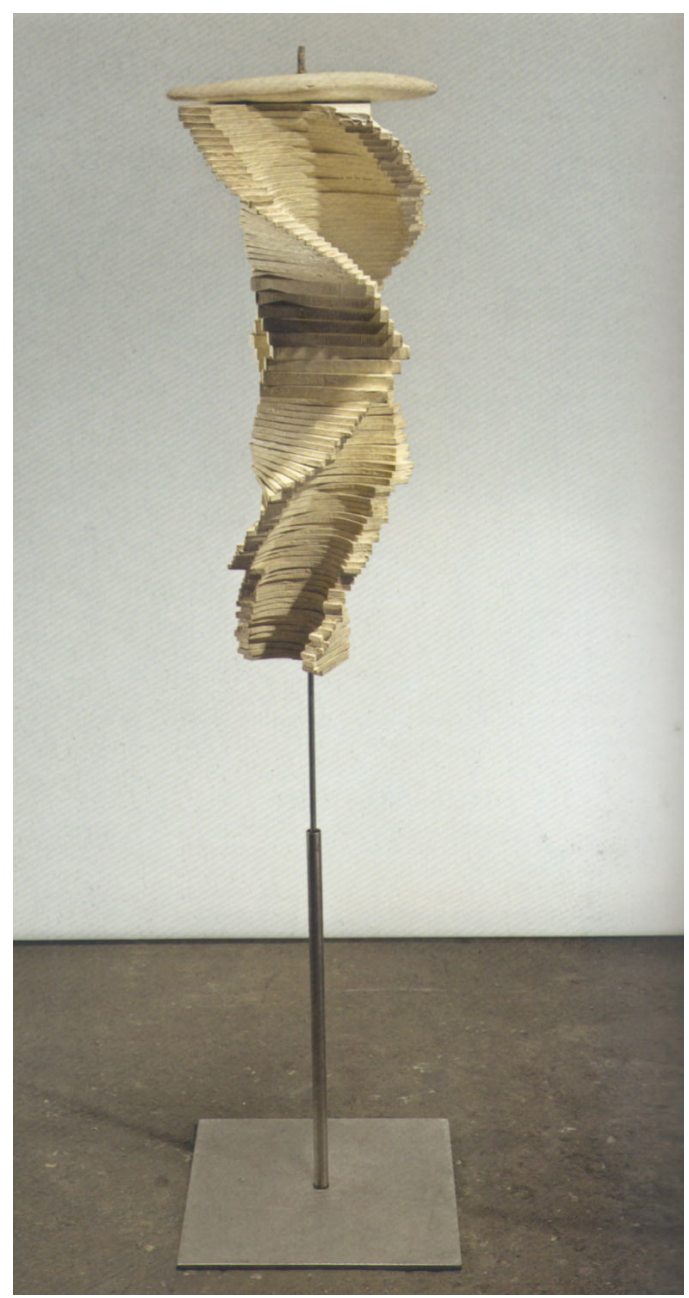

Figura 5. Spiral Woman (1951-52). Madera pintada y acero inoxidable. 127 x 30,5 x $30,5 \mathrm{~cm}$. Museum of Modern Art, Nueva York. (Morris et al., 2007, p. 280) 


\section{El Movimiento de Retorno-Vuelta-Desplazamiento-Cambio}

La revuelta, pues, como retorno-vuelta-desplazamiento-cambio, constituye la lógica profunda de cierta cultura que quisiera rehabilitar, una cultura cuya agudeza me parece hoy seriamente amenazada. Pero volvamos de nuevo al sentido de esta revuelta que, en mi opinión, caracteriza de forma tan profunda a lo más vivo y prometedor de nuestra cultura. (Kristeva, 2000, p. 17)

Louise Bourgeois fue una artista en constante movimiento, fluyendo entre materiales, técnicas o expresiones plásticas. En París y Nueva York, epicentros mundiales del arte, Bourgeois estableció estrechas relaciones con artistas, arquitectos, coleccionistas y críticos, relaciones que enriquecerían e influirían en su propia concepción del arte.

Como expone Frances Morris, Bourgeois siempre estuvo dispuesta a asumir un nuevo reto y tuvo una gran capacidad para reinventarse hasta el final de su trayectoria. Morris compara a Louise Bourgeois con Francis Bacon y Alberto Giacometti, los describe como los tres grandes artistas del siglo XX que trabajan en los márgenes de la corriente dominante, fuertemente solitarios y grandes existencialistas. En cada década, en cada trabajo, siempre vuelven al mismo grupo de poderosos temas. Sin embargo, Bacon y Giacometti se diferencian de Bourgeois en que su obra es absolutamente reconocible, ambos investigan a lo largo de su carrera manteniendo el mismo lenguaje visual, estético y formal. En cambio, Bourgeois reinventa los términos de su compromiso con el arte en cada etapa. El núcleo se mantiene allí, pero la manifestación física es completamente diferente. Y es esta gran diversidad formal y estética la que hace que su trabajo sea tan atractivo e innovador. Cada tema se aproxima desde una perspectiva técnica y material completamente diferente, incluso cuando es una artista nonagenaria sigue siendo capaz de enfrentarse a un nuevo reto y asumir una nueva técnica o un nuevo material generando una propuesta original (Morris \& MOCA, 2008).

Pero lejos de ser una evolución lineal, el recorrido de Bourgeois se caracteriza por un movimiento recurrente de vuelta y revuelta. Bourgeois reflexiona y representa este movimiento a través del símbolo de la espiral y de los lemas "hago, deshago, rehago" y "recuperar, reparar y resucitar".

La espiral es omnipresente en el trabajo de Bourgeois. La encontramos en formatos y materiales muy diferentes a lo largo de su dilatada carrera. 
Bourgeois otorga variados significados a este símbolo. He aquí algunos ejemplos:

La espiral es el comienzo del movimiento en el espacio. (Louise Bourgeois, 1989, en Morris et al., 2007, p. 279)

La espiral es importante para mí. Es una vuelta de tuerca. Cuando era niña, después de lavar los tapices en el río, los doblaría, los retorcería y los escurriría junto con otras personas, para eliminar todo el agua de ellos. En el futuro, soñaría con deshacerme de la amante de mi padre. Lo haría retorciéndole el cuello. La espiral -me encanta la espiralrepresenta control y libertad. (Louise Bourgeois, 1994, en Morris et al., 2007)

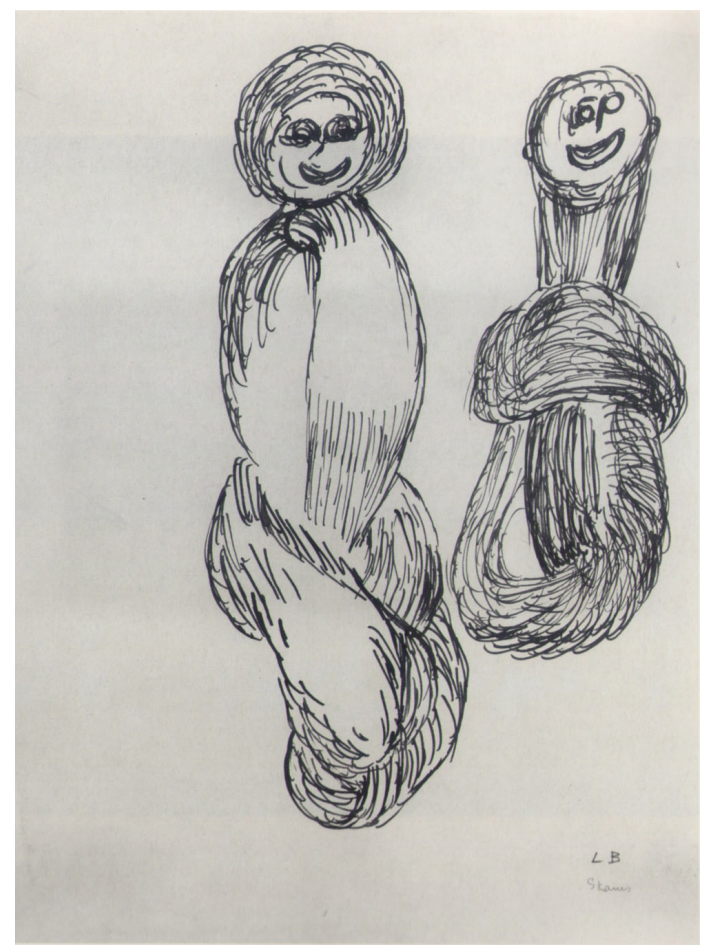

Figura 6. Skains (1943). Tinta china sobre papel gris. 30,5 × 22,9 cm. Galerie Lelong, Zurich. (Tàpies et al., 1990, p. 43) 
[...] Al ser hija de Voltaire y al tener una educación racionalista del siglo XVIII, creo que si se trabaja lo suficiente, el mundo será mejor. Si trabajo tantísimo en todos estos artilugios, "conseguiré el pájaro que quiero" [pero aún así] el resultado final es más bien negativo. Por eso sigo adelante. La resolución nunca llega; es como un espejismo. No obtengo satisfacción - de lo contrario me detendría y sería feliz. (Bernadac et al., 1998, p. 162)

La segunda representación de la revuelta bajo el lema "hago, deshago y rehago" es la traducción literal del título de la obra I Do, I Undo, I Redo (1999-2000), formada por tres torres de acero que Bourgeois concibió para ser instaladas en la gigantesca entrada de la Tate Modern. Este enunciado describe el proceso de ida, vuelta y revuelta que tanto caracterizó su obra. Lo que Bourgeois había creado, podía deshacerlo y rehacerlo meses o años después. Retomaba lo ya hecho, lo cuestionaba, lo reconstruía y lo retrabajaba desde la perspectiva actual, es decir, desde otra perspectiva, otorgándole una nueva vida con significado propio.

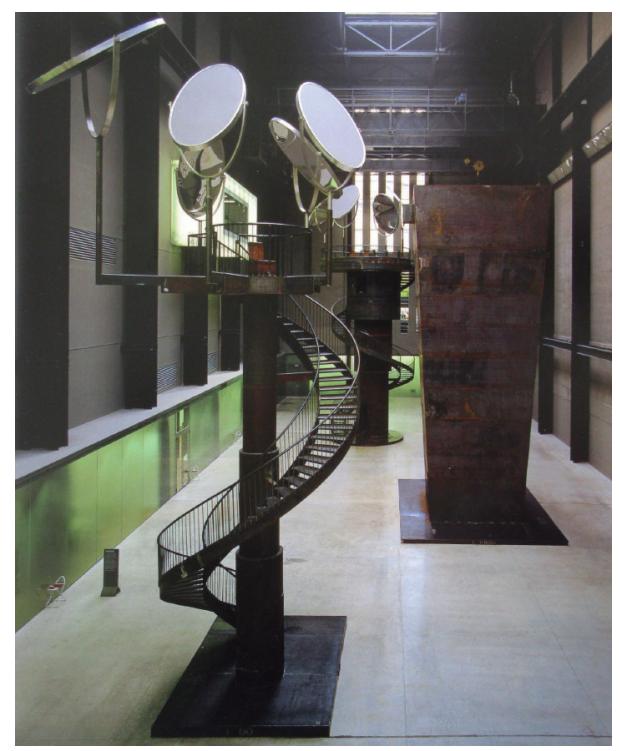

Figura 7. I Do, I Undo, I Redo (1999-2000). Tate Modern. Foto de Marcus Leith y Andrew Dunkley. Cortesía de Cheim \& Read, Nueva York. (Warner \& Morris, 2000, p. 33) 
La tercera versión de la revuelta como máxima se traduce literalmente como "restaurar, reparar y resucitar". "Restaurar" entendido en el sentido de recuperar, "reparar" como la acción de enmendar, y "resucitar" referido en su sentido más coloquial, como renovar o dar nuevo ser a algo. ${ }^{4}$ Bajo este lema surgen espontáneamente otro tipo de analogías con un fuerte componente humano, relacionado con la psicología y la religión. Se asocia con el hecho de sentirse mal por algo y querer enmendar o corregir la situación. Tiene que ver con la conciencia y con la culpa, con los valores y con la autoestima, con la intencionalidad y con el autocontrol. Su movimiento último será hacia la resurrección, la capacidad de renovar el punto de vista sobre lo acontecido dándole una nueva forma, una nueva vida desde la compasión, el perdón y el reposo.

Psicoanalíticamente hablando, hay una poderosa conexión con el sentimiento de culpa. Todas las Cells [conjunto de instalaciones arquitectónicas que Bourgeois creó entre 1991 y 2001] tienen un tono confesional. Ellas expresan las ideas de restauración, reparación y resurrección tan cruciales en el proceso creativo de Louise. Hay una extraordinaria vinculación entre ella -su mente y el cuerpo- y el proceso de producción de la obra. Es casi como, si al salvar estas piezas, se estuviera salvando a sí misma reparando el daño que había hecho a los demás. (Jerry Gorovoy en Lorz et al., 2015, p. 42)

Muy al final de su trayectoria encontramos dos Cells confesionarios. El primero The Confessional (2001) se pudo ver en la Galería Soledad Lorenzo en Madrid. Es un confesionario frío, de paredes metálicas y opacas.

El segundo está instalado en la Église de Louise Bourgeois que se inauguró en 2004 en el Convento d'ô, en Bonnieux, Francia. ${ }^{5}$ En el exterior, en la parte lateral superior de la estructura oval del confesionario encontramos grabadas las siguientes palabras: "Renunciation, Reconciliation, Resurrection, Reparation, Restoration, Redemption". 


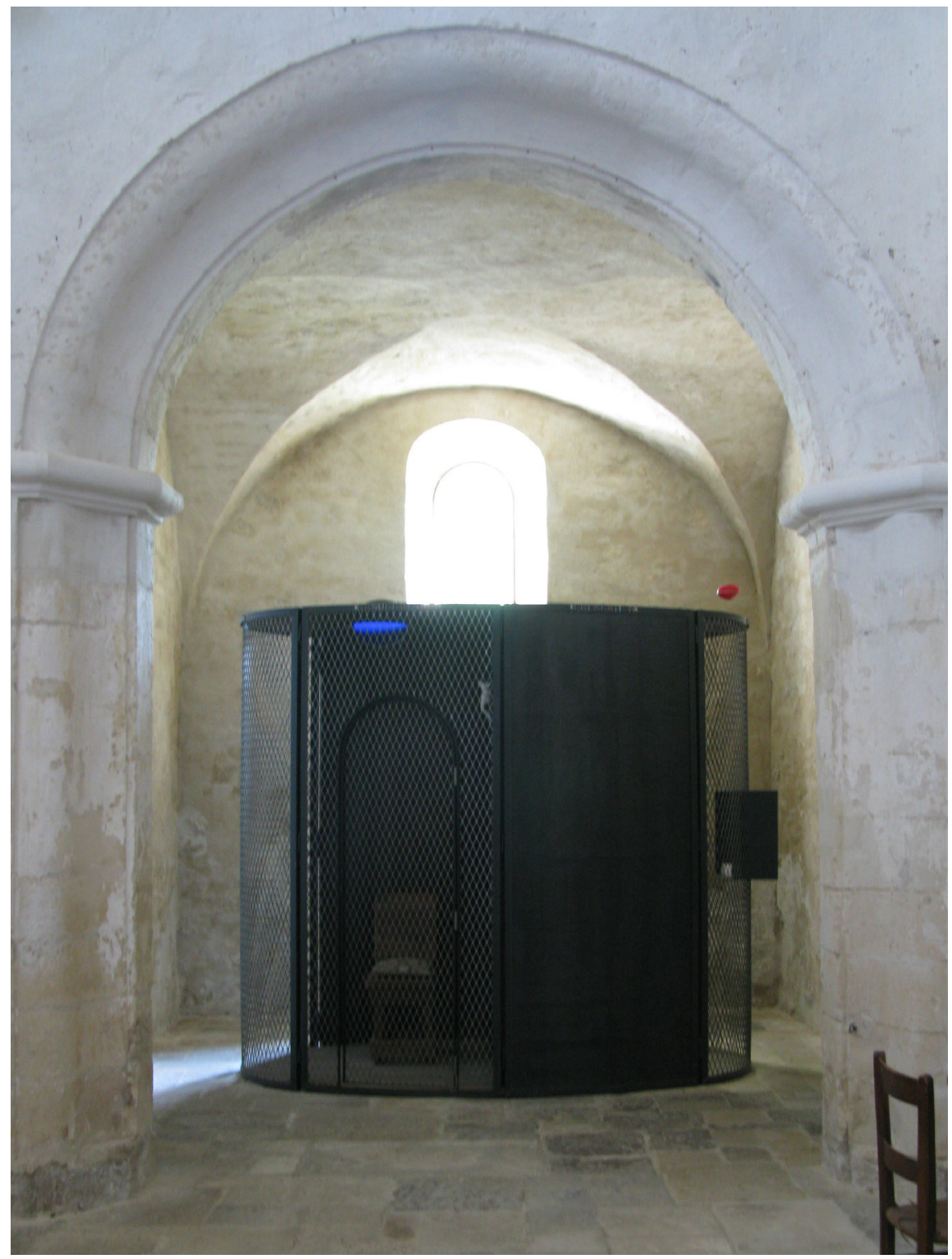

Figura 8. Église Louise Bourgeois (2004). Imagen del confesionario. Le Couvent d'Ô, Bonnieux, Francia. Foto de Alexandra Sans Massó 
Pero, ¿qué es lo que Bourgeois restaura en este ir y venir? ¿Hacia dónde vuelve y revuelve su trabajo? Hacia un consistente núcleo temático. La obra de Bourgeois reelabora un mismo conjunto de temas, motivos o inquietudes, a los cuales interroga y desarrolla a lo largo de toda su trayectoria artística.

Aunque la mayor aportación de Bourgeois se haya producido en el ámbito de la escultura o arte tridimensional su carrera artística empezó con la pintura y rápidamente se diversificó resultando en una impresionante producción de grabados, dibujos, tejeduría y escritura. De la misma manera, la artista sobresalió por su maestría trabajando gran cantidad de materiales, manipulándolos directamente o dirigiendo a profesionales en la producción de sus obras. Tanto es así que cuando uno investiga el trabajo de Bourgeois por primera vez, puede perderse con facilidad ante su abrumadora diversidad formal, técnica y estética. Sin embargo, al profundizar en su trabajo, se descubre que es fuertemente consistente en su contenido temático durante las más de siete décadas en las que se expande.

Me gustan Messerschmidt, Soutine, Kokoschka y Gaston Lachaise. Entiendo sus contenidos. Lachaise hizo la misma mujer toda su vida; ya sabe usted que a mí me gusta la repetición en la temática. (Lo formal es otra cuestión.) Los asuntos son universales, pero la manera que tenemos de expresarlos es muy personal. Como dijo Pascal, 'El estilo es el hombre'. El estilo no es una cosa consciente; el estilo eres tú. (Louise Bourgeois, c.1986, en Müller-Westermann \& Vuong, 2015, p. 30)

Aunque no se trata de una mera repetición temática causada por una decepción recurrente en la expresión de la artista, sino que las obras de Bourgeois con frecuencia son deliberadamente polisémicas y ambiguas, complejas y misteriosas. Poseen una riqueza de significación que se consigue gracias a esta revuelta a unos mismos temas desde perspectivas temporales y circunstanciales diferentes. Estos temas requieren una re-presentación material singular y se relacionan con nuevos elementos en la expresión de significado.

El arte de Bourgeois siempre tiene un precedente, una genealogía, un pasado que cabe buscar en su propia obra y mucho más allá de ella, y que se nutre de la historia y de la prehistoria, de la ciencia y de la literatura, de la psicología y de la mitología y sobre todo, de su experiencia personal. 
Si me preguntan qué quiero expresar, entonces tiene más sentido. Aquí al menos hay un misterio del que podemos hablar, ya que durante toda la vida he querido decir lo mismo. La consistencia interna es el test del artista.” (Louise Bourgeois, 1969, cit. en Bernadac et al., 1998, p. 91)

Para ejemplificar esta revuelta a un núcleo temático se presentan tres series con un mismo referente o tema en la obra de Bourgeois: protuberancias, arañas e hijos daga. Cada una de ellas se presenta con seis obras en orden cronológico.

\section{Protuberancias}
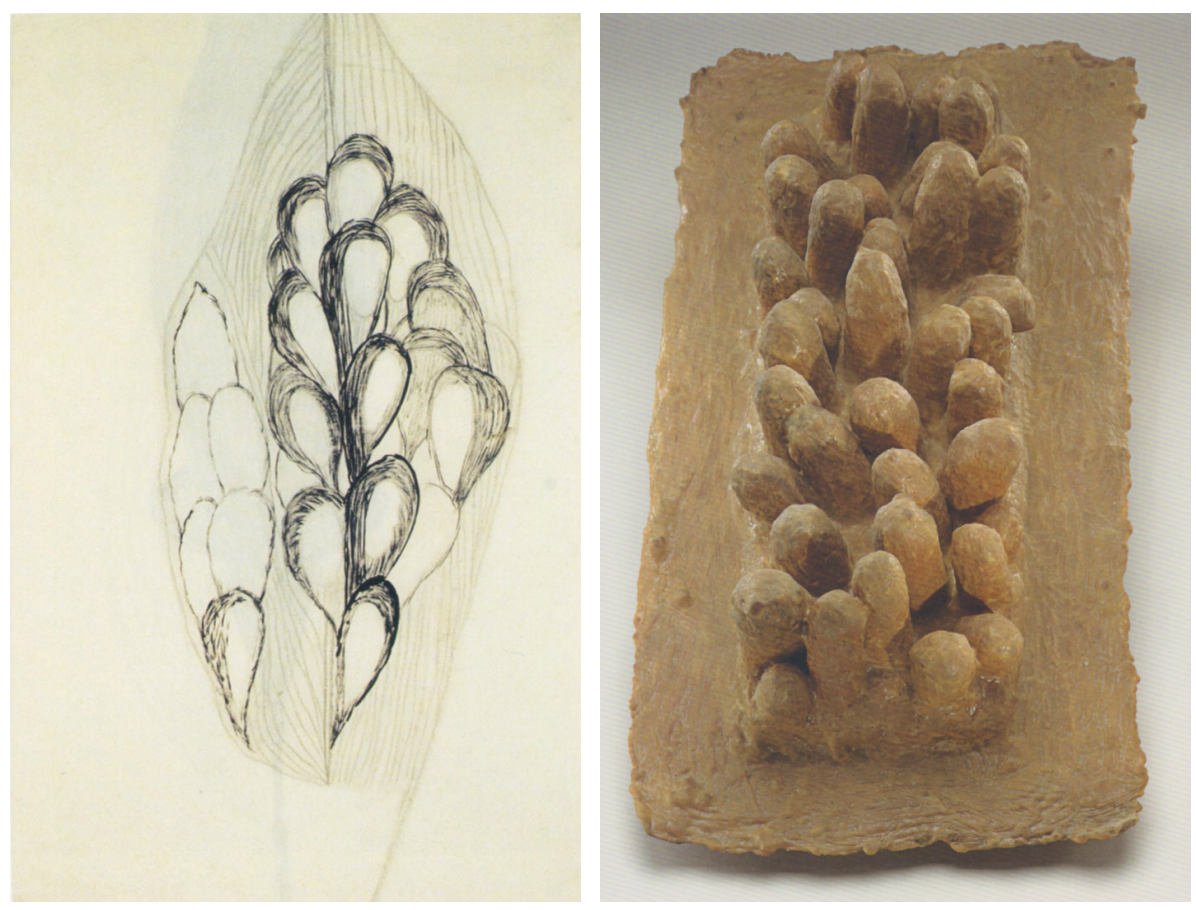

Figura 9. Sin título (1948-51). Tinta sobre papel. 50,1 x 32,3 cm. Sarah-Ann \& Werner H. Kramarsky. (Kellein, 2006, p. 94)

Figura 10. The Fingers (1968). Látex y escayola. 8,3 x 44,5 x 22,9 cm. Foto de Christopher Burke. (Larratt-Smith 2012, plate 31) 

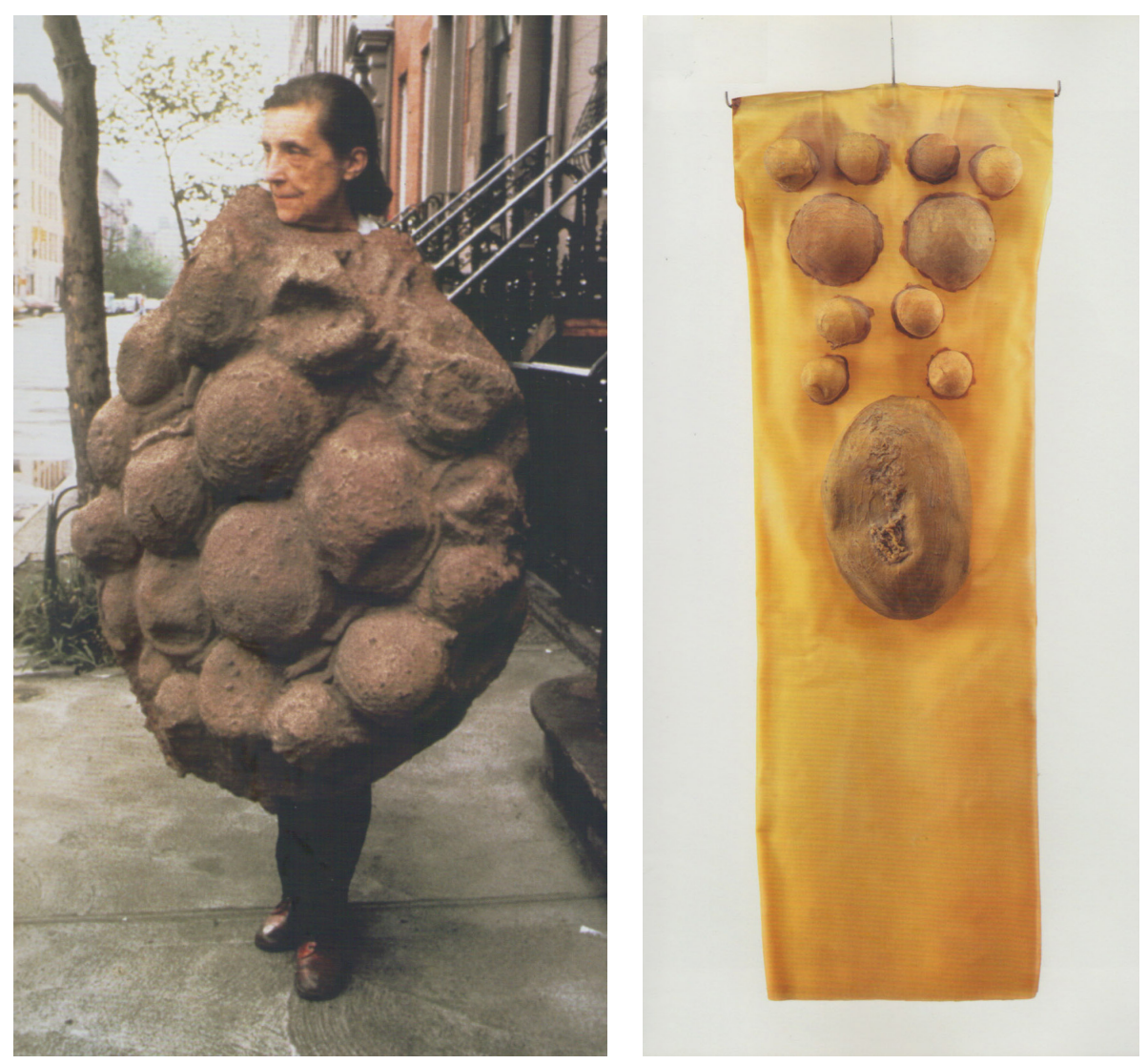

Figura 11. Louise Bourgeois en las escaleras de su casa en Nueva York, en 1975, llevando la escultura de látex Avenza que formaría parte de Confrontation (1978). Foto de Peter Moore. (Hauser \& Wirth, 2010, p. 45)

Figura 12. Costume for the Performace A Banquet/A Fashion Show of Body Parts (1978). Látex. 153 x 53 x $13 \mathrm{~cm}$. Colección The Easton Foundation. (MüllerWestermann \& Vuong, 2015, p. 95) 


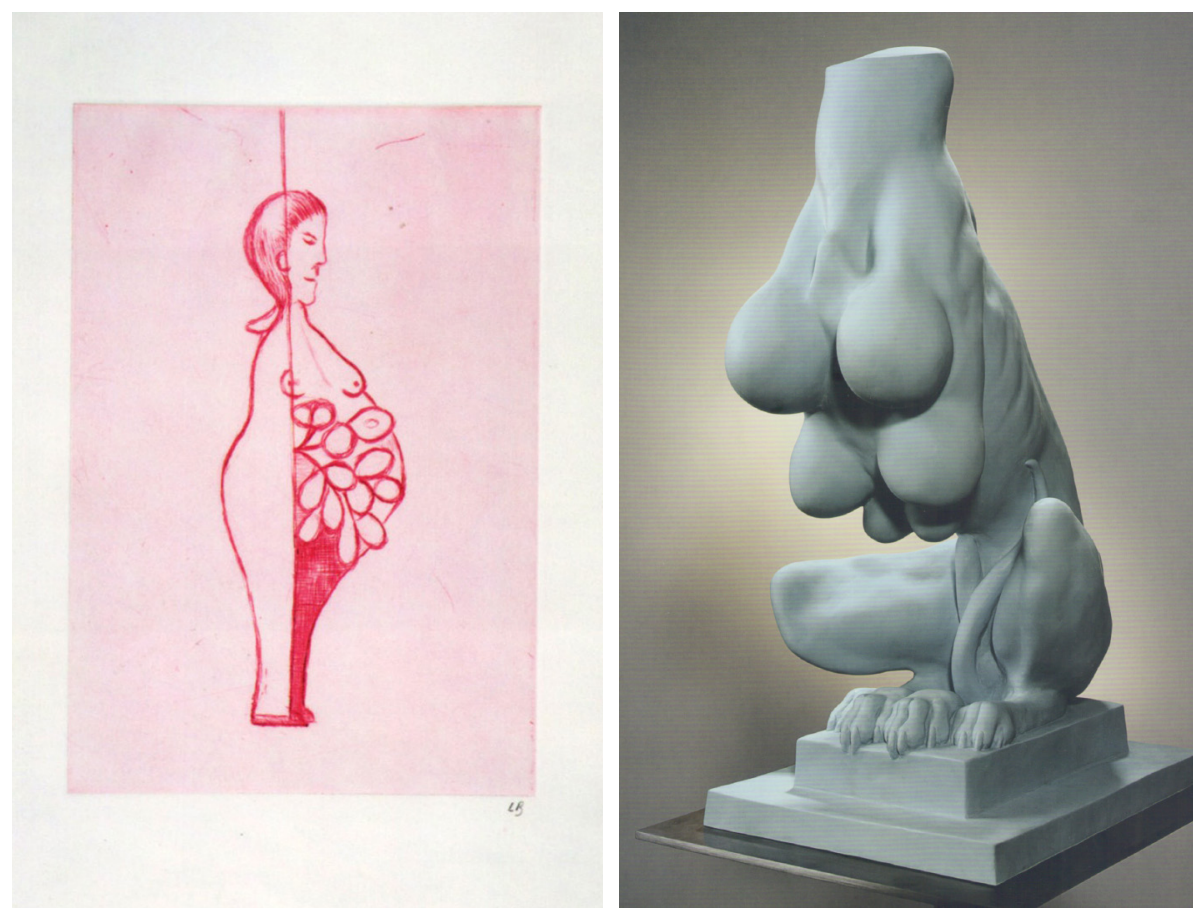

Figura 13. Girl Falling (1993). Punta seca y tinta roja sobre papel. $38,1 \times 27,9 \mathrm{~cm}$. (Kellein, 2006, p. 210)

Figura 14. Nature Study (1984-2002). Goma azul. 76,2 x 48,3 38,1 cm. Foto de Christopher Burke. (Larratt-Smith 2012, plate 46) 


\section{Arañas}


Figura 15. Spider (1947). Tinta y carboncillo sobre papel marrón. 29,2 x 22,2 cm. Colección particular. Nueva York. (Tilkin, 2012, p. 22)

Figura 16. Spider (1994). Acero. 247,6 x 802,6 x 596,8 cm. Photo Peter Bellamy. Colección Museo Nacional Centro de Arte Reina Sofia, Madrid. (Warner \& Morris, 2000, p. 61) 



Figura 17. Sin título (1 de 9 imágenes de Ode à ma mère) (1995). Punta seca. $30 \mathrm{x}$ $29.9 \mathrm{~cm}$. The Easton Foundation. (http://www.moma.org/)

Figura 18. Spider (1997). Acero 238,7 x 243,8 x 213,3 cm. Foto de Christopher Burke. Colección privada, Francia. (Warner \& Morris, 2000, p. 64) 

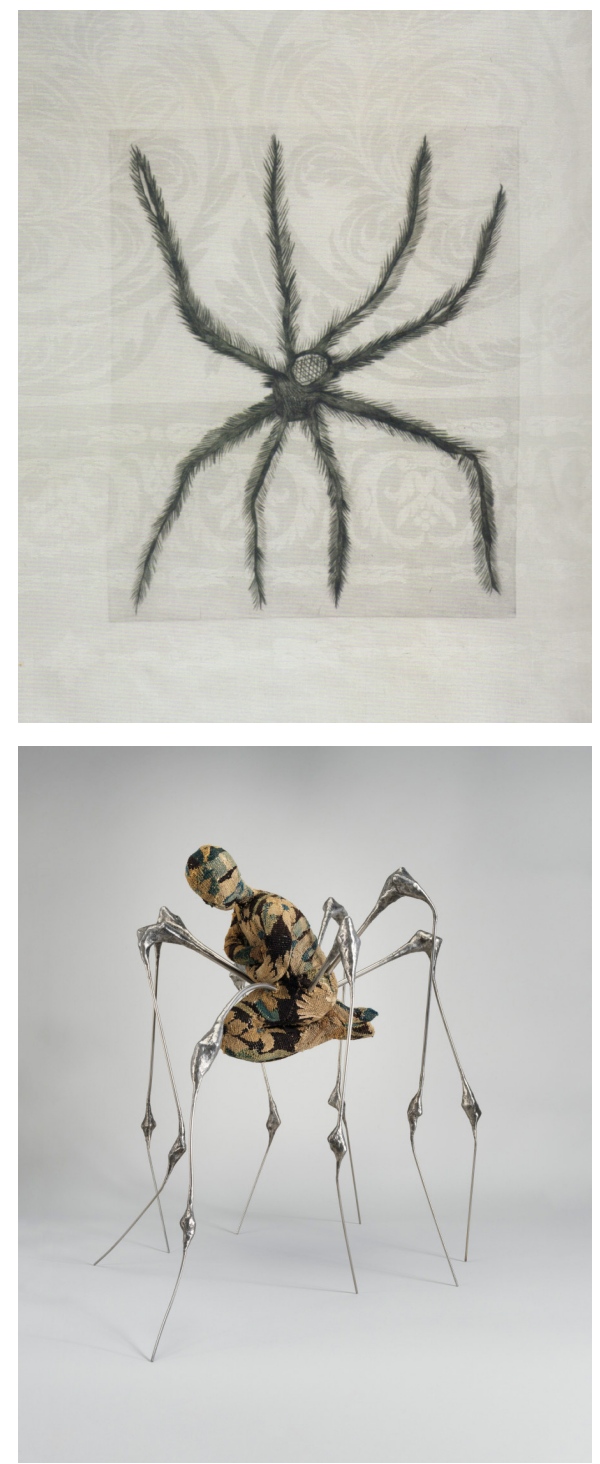

Figura 19. Hairy Spider (2001). Punta seca 48.3 x $40.6 \mathrm{~cm}$. Brooklyn Museum. Robert A. Levinson Fund. (https://www.brooklynmuseum.org)

Figura 20. Spider (2003). Colección The Easton Foundation. Foto de Christopher Burke. (Davies, 2015) 


\section{Hijos Daga}
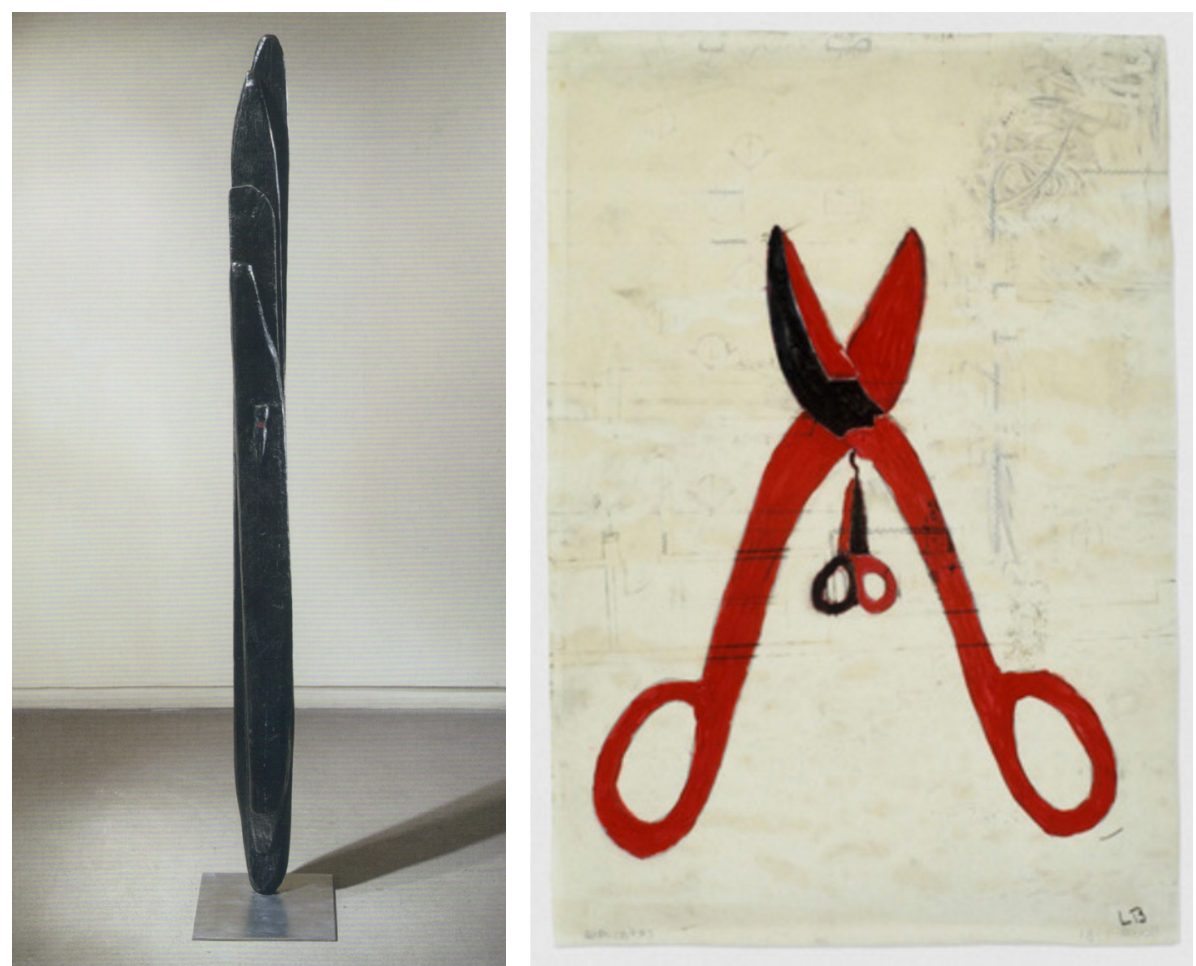

Figura 21. Dagger Child (1947-49). Bronce, pintura y acero inoxidable. 62 x 40,6 x $20 \mathrm{~cm}$. Foto de Christopher Burke. (Larratt-Smith 2012, plate 6)

Figura 22. Sin título (1986). Tinta y lápiz sobre papel. 27,3 x 19,1 cm. The Easton Foundation (http://www.moma.org/) 

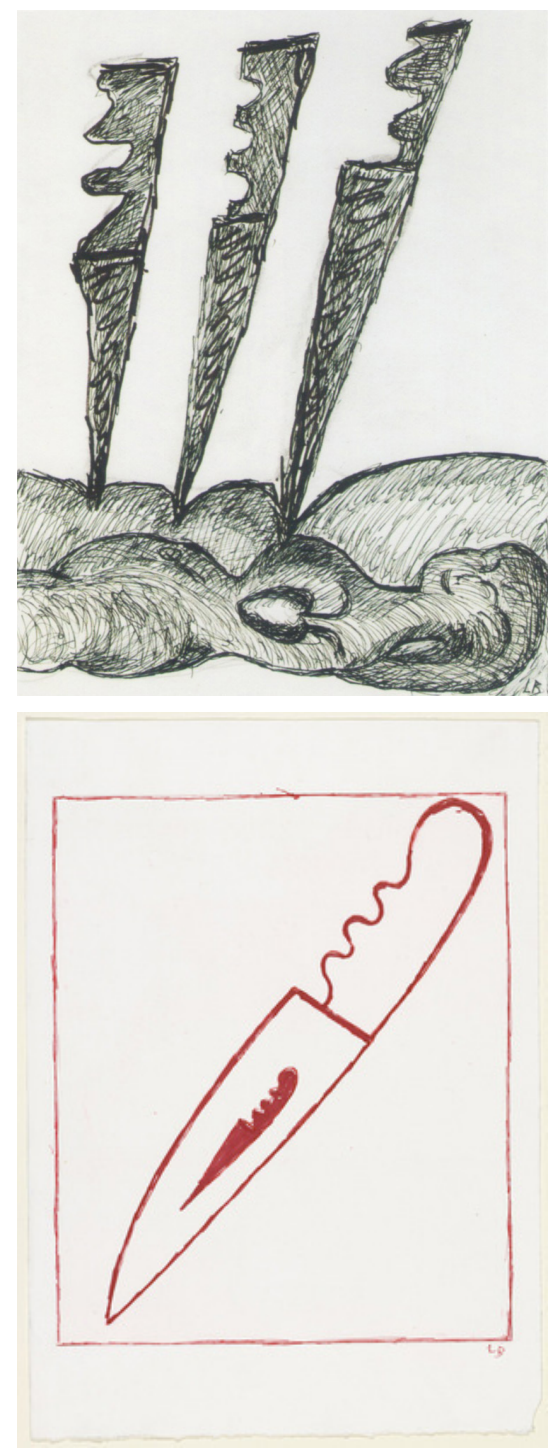

Figura 23. The Dagger Child Hurt the Parent (1998). Tinta, lápiz y carboncillo sobre papel. 29,2 x 22,8 cm. (Kellein, 2006, p. 103)

Figura 24. Dagger Child (2005). Punta seca con tinta roja añadida. 39,5 x 28,2 cm. The Easton Foundation. (http://www.moma.org/) 

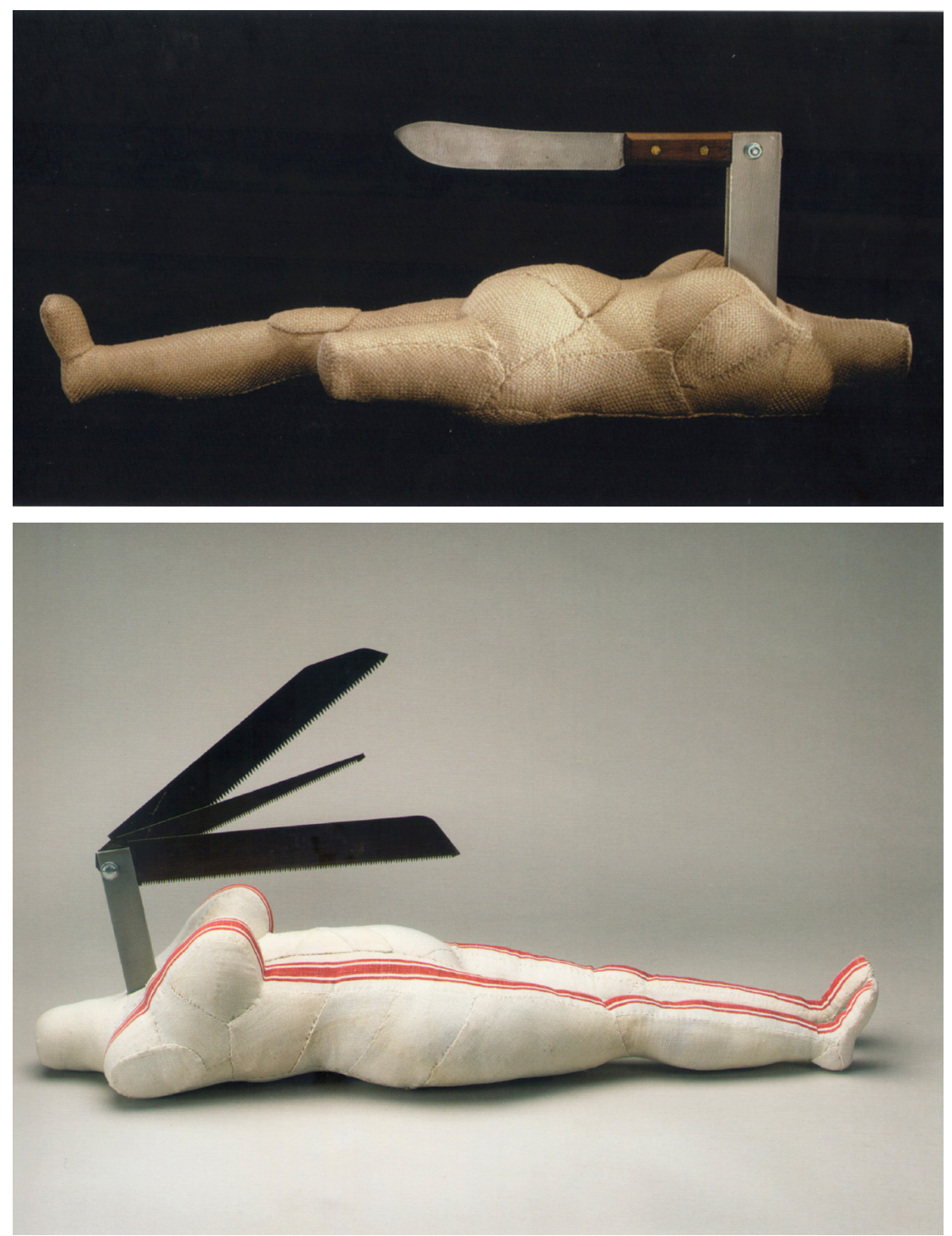

Figura 25. Femme Couteau (2002). Tela, acero y madera. 22,9 x 69,9 x 15,2 cm. Colección particular, Italia. (Tilkin, 2012, p. 57)

Figura 26. Femme Couteau (2002). Tela y acero. 35,6 x 68,6 x 17,8 cm. (Tilkin, 2012, p. 79) 


\section{Volver a lo Corpóreo}

"La vida está hecha de experiencias y emociones. Los objetos que he creado las hacen tangibles". (Gorovoy \& Asbaghi, 1997, p. 5)

La vuelta a lo corpóreo se refiere al énfasis en los aspectos más físicos y corporales del proceso de creación. Lo corpóreo es un concepto con diferentes vertientes relevantes en el análisis de la obra de Bourgeois. Por un lado, se trata de un arte que se desplaza constantemente hacia lo matérico, donde lo corpóreo -lo que tiene consistencia- es esencial. Un arte dirigido al sentido esencial del tacto, tangible, contundente. Se trata de una manera de expresarse que se contrapone a las grandes tendencias en el arte del siglo XX basadas en lo inmaterial, lo experiencial y lo efímero, y dirigidas al mundo digital y virtual que rige la vida occidental a principios del siglo XXI.

"En cierto sentido Louise Bourgeois reproduce constantemente su ser interior con la intención, supongo, de hacer un contacto táctil con el alma de su público, en lugar de uno intelectual." (Arthur Miller cit. en Kotik, Sultan, \& Leigh, 1994, p. 76).

En su segunda vertiente, lo corpóreo se refiere a lo relativo al cuerpo. Bourgeois retoma la representación de la figura humana, tan denostada a principios el siglo XX por ser uno de los elementos característicos del arte clásico y motivo principal de una expresión considerada burguesa y falta de significado. En el arte de Bourgeois el cuerpo reaparece con fuerza pero, muy lejos de la idealización clásica, Bourgeois lo reinventa, lo construye desde la experiencia de lo vivido desde su cuerpo de mujer, restaurándolo desde lugares muy distintos a los recogidos en la historia del arte y respondiendo a inquietudes contemporáneas relacionadas con la subjetividad, lo femenino y el psiquismo. En este sentido, el cuerpo en Bourgeois aparece fragmentado o completo, rígido o flexible, en grupo o en solitario, erguido o colgando, pero siempre contándo historias sustanciales a partir y desde él. 


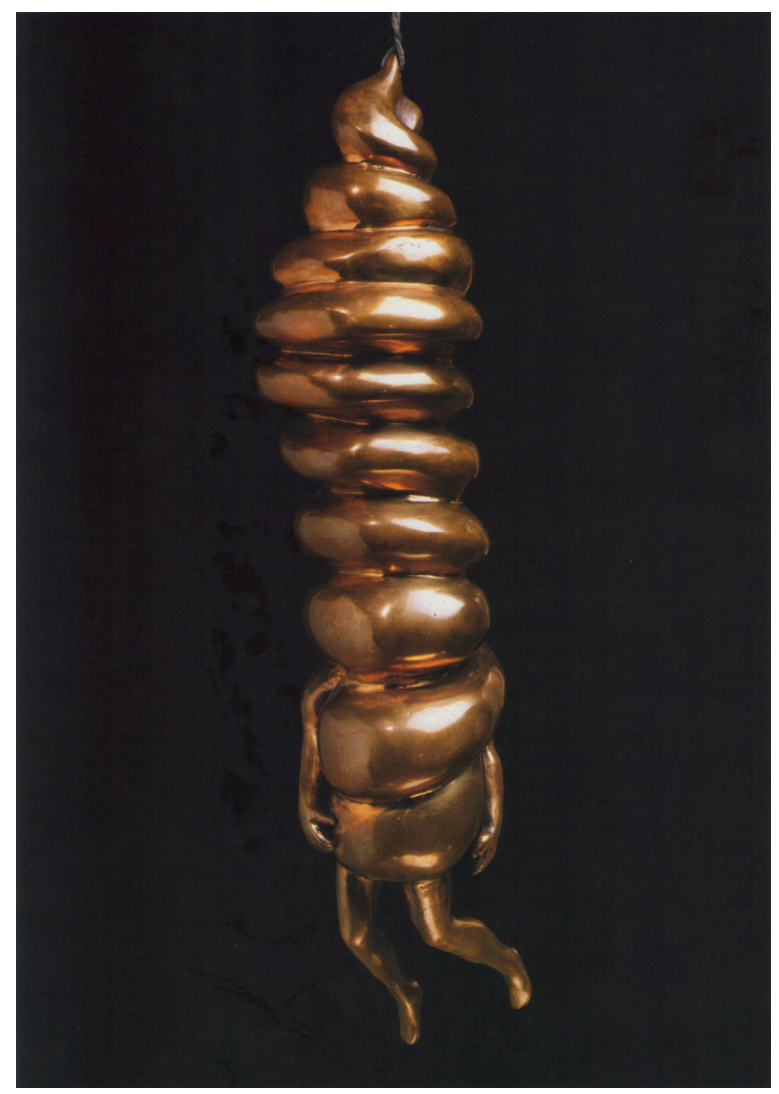

Figura 27. Spiral Woman (1984). Bronce. 48,2 x 10,1 x 13,9 cm. (Kellein, 2006, p. 133)

Por último, en su vertiente más simbólica, el cuerpo humano y el cuerpo escultórico comparten mecanismos y significados profundos. La escultura de Bourgeois confiere gran importancia al proceso de trabajo físico, que implica al cuerpo, donde intervienen destrezas y habilidades, pero también la fuerza, el peso y el equilibrio, entre otros aspectos. Es un arte en el que la corporeidad del artista impacta sobre los aspectos corpóreos del material, modificando su estado y su apariencia. A la vez es un arte en el que el proceso en la elaboración del cuerpo de la escultura permite a Bourgeois experimentar y trabajar sus propias emociones y síntomas corporales. 
Mi escultura me permite volver a experimentar el miedo, para hacerlo físico, así soy capaz de acabar con ello. El miedo se convierte en una realidad. La escultura me permite volver a vivir el pasado, ver el pasado de manera más objetiva y realista. (Meyer-Thoss, 1992, p. 195)

En su escrito para la exposición de la Fundació Tàpies en 1990, Robert Storr reflexiona sobre "la naturaleza provocativa y sincera del encuentro entre la subjetividad del creador y la objetividad de la realidad material" (Tàpies et al., 1990, p. 206). Es decir, reflexiona sobre aquello que sucede cuando la determinación del artista se encuentra con las propiedades reales del material con el que trabaja. Según él, muchos teóricos omiten la importancia de este "encuentro" cuando hablan del arte únicamente en función de causas psicológicas o de tendencias estilísticas. La forma final de la obra, además de resultar en un símbolo o arquetipo, es siempre el resultado de un encuentro físico y se constituye en una entidad concreta y sensual.

En 1969, William Rubin entrevistó a la artista para el artículo "Some Reflections Prompted by the Recent Work of Louise Bourgeois". En él habla de la importancia del proceso y de los significados e implicaciones emocionales que se derivan de éste, distinguiendo entre dos tipos de escultura, una de resultado inmediato y otra de tipo assemblage. "Si quiero expresar algo que es de inmediata y suma importancia para mí, haré una pieza inspirada en el fuerte deseo de decirlo (lo que sea), y lo haré de forma rápida y sin interrupción" (Rubin, 1969, pp. 84-85). En el segundo tipo, "un trabajo de assemblage", se crean relaciones entre las piezas que lo integran y en su conjunto adquieren un significado más potente que por separado. Es un tipo de escultura que requiere tiempo, concentración, análisis, y que tiene la dificultad de saber cuando hay que darlo por terminado. Bourgeois interpreta: "reunir es reconciliarse con las cosas" y Storr cree que se refiere no sólo a la reconciliación entre los objetos, sino que también a una reconciliación ritualizada entre el artista y el mundo tal como es. Articular la relación elemento a elemento tiene una función reconstituyente. Al contrario, cuando formas análogas se yuxtaponen o se apiñan evocan un sentido de fricción. (Robert Storr en Tàpies et al., 1990, p. 206) 


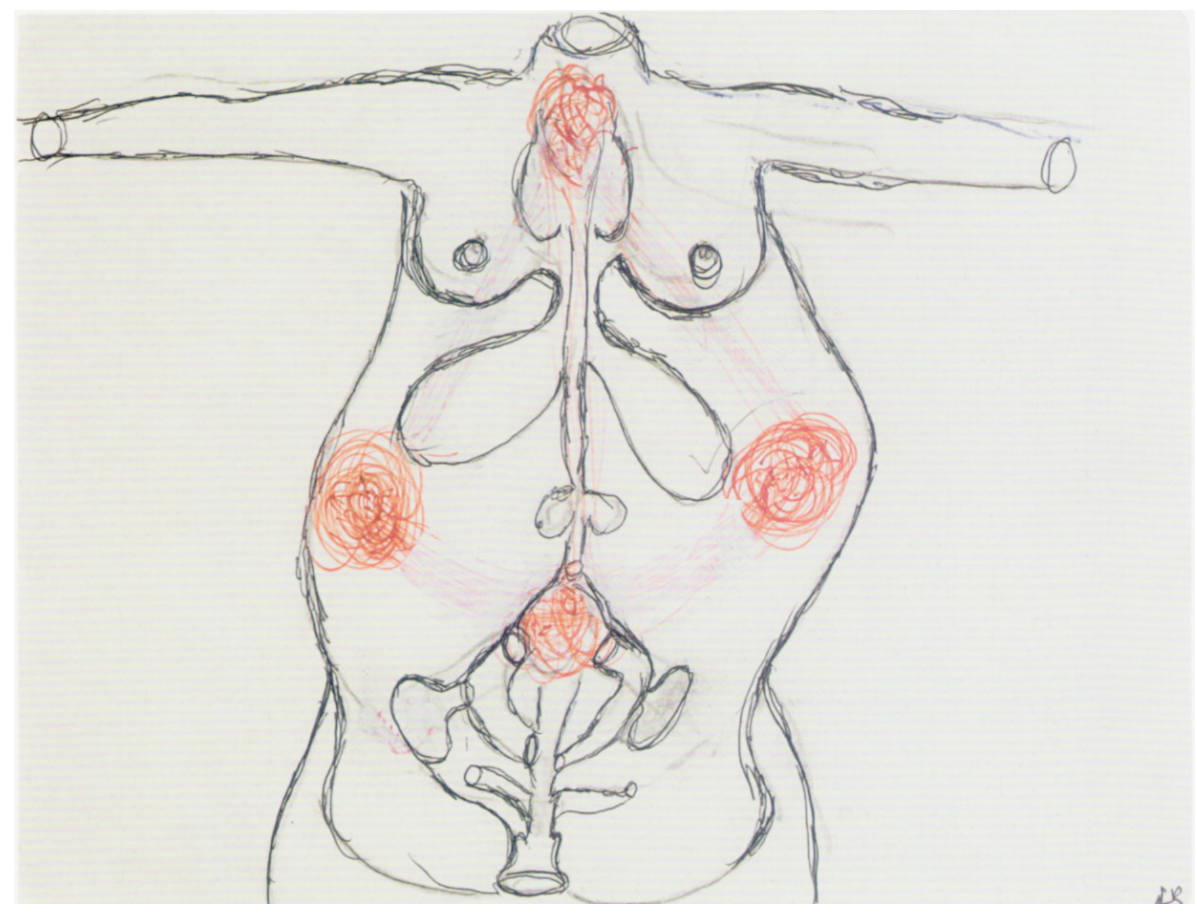

Figura 28. Spiral Woman (1984). Medical Horizontal (Doble cara) (1992) Tinta, lápices de colores y corrector. 22,9 x 30,5 cm. Foto de Christopher Burke. (Larratt-Smith 2012, plate 71)

Para Bourgeois los mecanismos corporales -íntimamente relacionados con la psique- se comportan análogamente a como lo hace el cuerpo de su escultura. A través del trabajo escultórico revive ciertos procesos físicos, psíquicos o emocionales que la artista reelabora a través del trabajo escultórico con la materia, es decir, que vehicula su revuelta psíquica a través de su cuerpo escultórico.

Organizo una escultura de la forma en que organizamos un tratamiento para los enfermos. Será mejor que sepas lo que estás haciendo. Tienes que tener una estrategia para obtener los resultados deseados. Mis esculturas son ecuaciones infalibles. Las ecuaciones tienen que ser probadas. ¿Baja la tensión, se ha eliminado la compulsión, se ha ido el 
dolor? O bien funciona o bien no funciona.” (Louise Bourgeois, 1992, en Bernadac et al., 1998, p. 226)

Para terminar, cabe destacar una reflexión clave de Kristeva sobre Bourgeois en relación al cuerpo, su mecanismo y el proceso de sublimación que la artista conjuga en su arte:

No estoy interesada en el cuerpo: estoy interesada en el mecanismo." Por supuesto: el cuerpo es un mecanismo y el mecanismo es más fuerte que el cuerpo; más fuerte que la mujer, más fuerte que el hombre, más fuerte que el miedo o la muerte. El cuerpo se transforma en un mecanismo; ¿es esto a lo que llaman 'sublimación'? Ella/Pequeña Guisante lee a Freud. No lo admite, pero ella misma lo pone de manifiesto: "Todo conduce [a] tu capacidad de sublimación. (Kristeva, 2007, p. 247)

\section{Reflexiones a Modo de Conclusión}

El concepto de revuelta en la obra de Bourgeois se mueve entre las fronteras de lo psicológico, lo artístico y la simbólico.

El psicoanálisis como revuelta en la obra de Bourgeois es el planteamiento más fundamental presentado en este artículo puesto que la revuelta de Kristeva nace de su propia experiencia con el psicoanálisis. Los escritos psicoanalíticos de Bourgeois publicados en 2012 arrojan mucha luz sobre este tema y desvelan la gran importancia que tuvo esta práctica en la obra de Louise Bourgeois. Este es un terreno fértil sobre el cual ya están investigando profesionales de diferentes ámbitos y que hasta ahora no ha sido investigado en profundidad. De la misma manera sería sustancial investigar la recepción y aportación de la obra de Bourgeois a los profesionales del psicoanálisis.

La revuelta en el proceso y producción artística de Bourgeois es clave para entender su arte. Este artículo propone el motivo de la espiral y los lemas "I Do, I Undo, I Redo" y "Restoration, Reparation, Resurrection" como símbolo y lemas del constante movimiento de retorno a un núcleo temático en su extensa producción. Se debería desarrollar la relevancia de estas tres propuestas como enunciados de la revuelta en la obra de Bourgeois. También se ha ilustrado el retorno a unas preocupaciones centrales con la presentación de tres series temáticas. Sería interesante discernir cuales son las series más 
recurrentes y significativas de su obra y observar la relación que se establece entre las diferentes piezas que conforman una serie. Y, dando un paso adelante se podría reflexionar sobre los matices y diferencias que cada una de ellas aporta en la creación de una simbología personal, otorgando profundidad a su lenguaje artístico.

La revuelta de lo corpóreo presenta el trabajo de Bourgeois como una reivindicación de lo tangible, matérico y corporal en lo escultórico. Su obra enaltece el aspecto táctil de la escultura a través de una obra sensual y matérica donde el objeto escultórico sigue siendo protagonista en la deriva de la escultura tradicional hacia el denominado arte tridimensional. Por otro lado, Bourgeois retoma con originalidad la representación del cuerpo humano, abordándolo desde las preocupaciones más contemporáneas. Finalmente, Bourgeois reflexiona sobre como vehicula y elabora las reacciones psicosomáticas de su cuerpo -que se producen cuando revuelve su pasado de manera consciente o inconsciente- a través de los procesos de creación del cuerpo de su escultura. Una vez expuesto el concepto de revuelta de Kristeva como teoría interpretativa y práctica generadora en el arte de Bourgeois, cabría analizar cómo a su vez el arte que ella produce, y en especial su serie Cells, se convierte en la representación de un espacio para la revuelta. Esta interpretación que debería desarrollarse en un siguiente ensayo

\section{Notas}

${ }^{1}$ Las traducciones de las citas al español han sido realizadas por la autora del artículo.

${ }^{2}$ En algunos verbos se ha optado por escribir el prefijo re separado por un guión para enfatizar la reiteración del sentido principal del verbo.

${ }^{3}$ Louise Bourgeois: The Spider, the Mistress, and the Tangerine, 2008.

${ }^{4}$ Definiciones de "restaurar", "reparar" y "resucitar": diccionario de la Real Academia Española en línea (http://lema.rae.es/drae/?val=), 17 de septiembre de 2015.

${ }^{5}$ En mi visita no había títulos ni fechas para las obras expuestas en el lugar, así que no se puede completar la citación para este confesionario. 


\section{Referencias}

Bernadac, M.-L., Bourgeois, L., \& Obrist, H.-U. (1998). Destruction of the father reconstruction of the father: writings and interviews 1923-1997 (Fourth pri.). London: Violette Editions.

Bourgeois, L. (1982). A project by Louise Bourgeois. Artforum, 21 (no 4, December), 40-47.

Daniel, M., Nixon, M., Fer, B., Mitchell, J., Morris, F., Nochlin, L., \& Garb, T. (2007). Louise Bourgeois conference audio recordings $\mid$ Tate. Tate publishing. Retrieved April 28, 2015, from http://www.tate.org.uk/ context-comment/audio/louise-bourgeois-conference\#open243012

Davies, L. (2015, August 14). Inside artist Louise Bourgeois' New York home. The Telegraph. Retrieved from http://www.telegraph.co.uk/ culture/art/10890373/Inside-artist-Louise-Bourgeois-New-York-home. html

Gorovoy, J., \& Asbaghi, P. T. (1997). Louise Bourgeois: Blue Days and Pink Days. Milan: Fondazione Prada.

Greenberg, J., \& Jordan, S. (2003). Runaway Girl: The Artist Louise Bourgeois. Michigan: Harry N. Abrams.

Hauser \& Wirth. (2010). Louise Bourgeois: The Fabric Works H\&W Press

Release. Hauser \& Wirth webpage. Retrieved August 10, 2015, from http://cloud.hauserwirth.com/documents/0UJhi6r4s5m9uSk651L1W

A17Yf610q7zsdqx0BjEa7Nd2AbgE8/lbourgeois_hwl2010_ptxthr3u34D0Q.pdf

Kellein, T. (2006). Louise Bourgeois. La famille. Köln: Walter König. Kotik, C., Sultan, T., \& Leigh, C. (1994). Louise Bourgeois. The Locus of Memory, Works 1982-1993. New York: The Brooklyn Museum, Harry N. Abrams.

Kristeva, J. (1998). L'Avenir d'une révolte. París: Calmann-Lévy.

Kristeva, J. (2000). El porvenir de una revuelta. (L. Miralles de Imperial, Trans.). Barcelona: Seix Barral.

Kristeva, J. (2007). Runaway Girl. Louise Bourgeois: From Little Pea

to Runaway Girl. In Louise Bourgeois (pp. 246-252). London: Tate Publishing.

Kuspit, D. (1988). An interview with Louise Bourgeois. (G. Speranza, Trans.). New York: Elizabeth Avedon Editions/Vintage Books. Kuspit, D. (2012). Louise Bourgeois in Psychoanalysis with Henry 
Lowenfeld. In P. Larratt-Smith (Ed.), Louise Bourgeois. The Return of the Repressed. Volume I (pp. 17-31). London: Violette Editions. Larratt-Smith, P. (2012). Louise Bourgeois. The Return of the Repressed.

Volum II: Psychoanalytic Writings. (P. Larratt-Smith, Ed.). London:

Violette Editions.

Larratt-Smith, P., Bronfen, E., Kuspit, D., Mitchell, J., Nixon, M.,

Verhaeghe, P., ... Harris Williams, M. (2012). Louise Bourgeois. The

Return of the Repressed. Volume I. (P. Larratt-Smith, Ed.). London:

Violette Editions.

Lorz, J., De Baere, B., Cooke, L., Fowle, K., Gorovoy, J., Pollock, G.,

Wilmes, U. (2015). Louise Bourgeois. Structures of Existence: The

Cells. (J. Lorz, Ed.). Munich: Prestel.

Meyer-Thoss, C. (1992). Designing for Free Fall. Zurich: Ammann.

Morris, F., Herkenhoff, P., Kristeva, J., Kuspit, D., Lebovici, E., Nixon, M.,

Storr, R. (2007). Louise Bourgeois. London: Tate Publishing.

Morris, F., \& MOCA. (2008). Frances Morris on Louise Bourgeois - MOCA

Podcasts. Stitcher. Los Angeles: MOCA - Museum of Contemporary

Art. Retrieved April 22, 2015, from http:/www.stitcher.com/podcast/ museum-of-contemporary-art-los-angeles/moca-audio-and-podcasts/e/ moca-audio-frances-morris-on-louise-bourgeois-15407467

Müller-Westermann, I., \& Vuong, L. (2015). Louise Bourgeois. I Have Been to Hell and Back. Moderna Museet, Stockholm, 14 febrero - 17 mayo 2015. Museo Picasso, Málaga, 15 junio - 27 septiembre 2015. (I. Müller-Westermann, Ed.). Stockholm: Moderna Museet.

Nixon, M. (2012). L. In P. Larratt-Smith \& E. Bronfen (Eds.), The Return of the Repressed (pp. 85-100). Violette Editions. Retrieved from http:// books.google.es/books?id=OnbpygAACAAJ

Paris, D. (2003). Julia Kristeva y la gramática de la subjetividad. Móstoles: Campo de Ideas.

Rubin, W. (1969). Louise Bourgeois: Questions and Answers. In Destruction of the Father. Reconstruction of the Father. (pp. 81-86). London:

Violette Editions.

Tàpies, M., Borja-Villel, M. J. ., Lippard, L. R., Storr, R., McEvilley, T.,

\& Krauss, R. (1990). Louise Bourgeois. Fundació Antoni Tàpies, Barcelona, novembre 1990-gener 1991. Barcelona: Fundació Antoni Tàpies.

Tilkin, D. (2012). Louise Bourgeois: HONNI soit QUI mal y pense.

La Casa Encendida, Madrid, 18 octubre 2012-13 enero 2013. 
Madrid: La Casa Encendida. Retrieved from http://books.google.es/ books?id=Ld2MmwEACAAJ

Warner, M., \& Morris, F. (2000). Louise Bourgeois. Tate Modern, Londres, 12 mayo-17 diciembre 2000. London: Tate Gallery.

Alexandra Sans Massó: Doctora en Bellas Artes por la Universidad de Barcelona.

Contact Address: Universidad de Barcelona. Facultad de Bellas Artes. Pau Gargallo, 4. 08028 Barcelona (España).

E-mail address: sansmasso@yahoo.es 